\title{
The financialisation of housing production: exploring capital flows and value extraction among major housebuilders in the UK
}

\author{
${\text { Tom } \operatorname{Archer}^{1} \text { (D) } \cdot \text { Ian Cole }}^{1}$
}

Received: 20 December 2019 / Accepted: 5 February 2021 / Published online: 27 February 2021

(c) The Author(s) 2021

\begin{abstract}
This paper examines trends in the operation and financial performance of major UK housebuilders shortly before, during and after the global financial crisis (GFC) in 2008. It outlines two contrasting explanations of what has happened in the sector over this period. The first is described as an 'institutional recovery' perspective, in which a period of initial retrenchment after the crash was followed by steady reinvestment, and then a cautious move back to growth by the major housebuilding companies. This is set against what we describe as a 'financialised recovery' perspective. This explanation stems from our own analysis of the annual accounts of major UK housebuilders since 2005. It reveals the impact of the intensive financialisation of a sector initially weakened by the GFC, but where the strategic primacy of maximising shareholder value has been asserted more strongly than before. Our analysis of dividend payments post-GFC reveals this in the starkest of terms. We suggest that the sector has been in more robust financial health than implied by the 'institutional recovery' narrative, but that significant value is being extracted out of these companies, and indeed the sector overall, by institutional investors. The analysis provides unique insights into the financialisation of housing production, an issue which to date has received only limited attention. We reflect on the implications of identified trends for housing supply in the UK. We also sketch future research possibilities to examine the ongoing impact of intensive financialisation and the capital flows into, and out of, major housebuilders.
\end{abstract}

Keywords Financialisation · Housebuilding $\cdot$ Housing supply

\section{Introduction}

This paper examines how financial processes connected with housing production in the UK have changed in the wake of the global financial crisis (GFC) of 2007/8. By tracking patterns from before the GFC emerged, it focuses on changes in the financial performance of the largest nine housebuilding companies that are responsible for developing

Tom Archer

tom.archer@shu.ac.uk

1 The Centre for Regional, Economic and Social Research, Sheffield Hallam University, Sheffield, UK 
nearly half of the annual housing output in the UK. ${ }^{1}$ Previous research (Payne 2015, 2019) into the performance of large UK housebuilders, based on accounts given by developers themselves, has suggested that these companies struggled to recover from the GFC and took time to reinvest, before moving into modest growth. Subsequently, their growth has been constrained by various factors, such as land availability, capacity and planning directives. However, our analysis shows that this narrative fails to take account of a central issue in these trends - the scale and impact of profit making and value extraction from the UK housing system since 2007/8.

In this paper, we assess an 'internal' narrative of institutional recovery against a broader analysis of trends revealed within the audited financial accounts of these companies. We trace movements in housing completions, profits and dividends in order to chart the patterns of capital flows in the sector. This analysis reveals a sharp increase in the scale of value extraction from the sector since 2010. We move on to estimate the consequences of this trend for the price of new dwellings and the level of housing completions that has been achieved. The paper is therefore intended as a contribution to literature on the financialisation of the housing system, focussed on housing production, examining recent trends in capital flows and value extraction. We tease out the implications for attempts to increase housing supply in the face of what the UK Government has itself described as a 'broken' housing market (MHCLG 2017).

In the following sections, we set out the specific focus of the paper, in relation to the broader literature on housing financialisation. The changing shape of the UK housebuilding sector is then charted, alongside insights into the responses of major housebuilders to the GFC. We then outline methods for more detailed analysis of financial processes, before presenting our analysis of housing output, revenue, profit making, and the use of dividends. The role of shareholders is then explored through a case study, examining the investments and value extraction by one major investor in UK housing. The paper finishes with a discussion of the implications of our empirical analysis for housing supply and for future research into housing financialisation.

\section{Blindspots in the analysis of housing financialisation?}

Real estate, including housing, performs a dual purpose in many modern economies, as both a tradable asset within financial markets, and as a commodity for private consumption (Aalbers et al. 2020). However these distinct, and sometimes competing functions, make it a weak link in many economic systems, made more apparent as real estate has been gradually transformed into liquid financial assets (Van Loon and Aalbers 2017). As scholars have grappled with these changes and their implications, there has been a rapid growth in literature on the financialisation of housing and other forms of real estate, with much of this focusing on the UK, USA and Europe (Aalbers 2016, 2017b; Fernandez and Aalbers 2016; Jacobs and Manzi 2019). Financialisation has become such a ubiquitous term that the question has been posed about whether the term retains any heuristic value, given its broad reach and the extent to which it has taken on different connotations in different contexts. Brett Christophers (2015) has called for a tighter delineation of the term, following on from

\footnotetext{
1 Size is determined by revenue derived from UK housebuilding activity. The tenth largest private housebuilder is not a publicly listed company, and hence, comparable data on financial and operational performance are not available.
} 
Engelen's (2008) concerns about the risks of 'conceptual stretching', so that it turns from a 'buzzword' to a 'fuzzword' (Ashman and Fine 2013, pp. 156-7). We would suggest that the word has not been emptied of all meaning and would follow the broad but serviceable definition of financialisation provided by Manuel Aalbers, as the "increasing dominance of financial actors, markets, practices, measurements and narratives, transforming economies, firms (including financial institutions), states and households" (Aalbers 2017a,).

Previous analyses of the financialisation of housing have tended to focus on organisations, products and individuals involved in the process of housing exchange. Past research, notably in European and US contexts, unveiled the financialising processes arising from, for instance, the privatisation of building societies as providers of mortgage finance (Boddy 1989; Martin and Turner 2000), the securitisation of mortgage loans (Aalbers and Engelen 2015; Wainwright 2009), and the rise of subprime lending (Langley 2008; Immergluck 2010). This focus has since been complemented by research into the impact of financialisation on organisations involved in housing investment and provision, which has covered issues such as the entry of private equity, hedge funds and Real Estate Investment Trusts (REITs) into the rental market (Fields and Uffer 2016; Waldron 2018). The rise of 'for profit' housing associations in the UK such as Sage (a subsidiary of Man Group) or Blackstone are also recent examples of what is likely to become a growing trend (Manzi and Morrison 2018), as elsewhere in Europe (Janoschka et al. 2019). The boundaries between non-profit and profit-making functions are increasingly blurred. This has not just been about the arrival of new 'players' in making funds available for capital investment; it is about the increasing penetration of public (Hodkinson 2011) and quasi-public sector (Gruis 2008; Mullins et al. 2017) agencies by financial capital and associated financial logics (Smyth et al. 2019). And these efforts to capture value from affordable housing are not the sole preserve of traditional financial actors. Public bodies, with responsibilities for delivering affordable housing, are also mirroring speculative activities, as they develop new vehicles to capture value from public assets. As Beswick and Penny (2018) show, some local authorities are replacing traditional social housing with new developments and new tenancies which enables such homes to become a liquid financial asset.

Such evidence may be situated in broader conceptions of present-day financialised capitalism, notably in Thomas Piketty's work Capital in the 21st Century (Piketty 2014). Piketty's underlying thesis about modern economies where $R>G$, when $R$ is the rate of return and $\mathrm{G}$ is the extent of capital growth or economic output, is of significance to studies of housing financialisation. Fernandez and Aalbers (2017) argue that what is required, in order to anchor these theories, is further empirical analysis of the cultural, geographical and sectoral differences in how the pattern of $\mathrm{R}>\mathrm{G}$ actually play out, not as the product of a free-floating economic 'law':

We argue that the institutional and ideational structure under which the "metamorphosis of capital" takes place is not a by-product of $\mathrm{R}>\mathrm{G}$ but central to its development and should therefore be at the heart of the analysis that tries to understand its variegation across space and time. (p. 152).

This asserts the importance of empirical studies which help us to understand the 'metamorphosis of capital' within different parts of the housing system, and in specific institutional and geographic settings.

One part of the housing system that has received little empirical attention to date, in terms of financialisation and role of financial actors, is that of housing production. Much of the focus in the literature so far has been on the way in which financial interests and logics have penetrated agencies in the public or the quasi-public sector. This process of 
encroachment or 'capture' does not apply in the same way to housebuilders, which are private companies from the outset. So the interest here is less on any underlying change of 'mission' among these organisations, or the impact of financialisation on the stated values of the companies, but more prosaically on what happens to the money-through changing capital flows and imposing a higher priority on extracting value from the production process. This has implications for outputs—getting new houses built. As housing supply is a primary concern of public policy, in the UK as elsewhere in Europe, this does differentiate housing from many other economic goods and services that the private sector produces.

Accounts given by housebuilders themselves suggest that they have been involved in an ongoing process of adaptation to changing market circumstances, derisking and moderating their return on investment in harder times, while moving to expansion when economic prospects improve. This narrative has been reflected in some of the research into the behaviour of major UK housebuilders in responding to the GFC (Payne 2015, 2019). More critical accounts of the role of housebuilders in the pursuit of financial gain at the expense of supply have focuses on their practices on land acquisition and speculation (Robertson 2017). We would, however, suggest this still gives a restricted view of the recent transformations in the UK housebuilding sector, by overlooking or marginalising the importance of flows of capital and value extraction.

The fact that few studies have been undertaken of processes for raising and distributing capital in housing production has been pointed out by Alice Romainville (2017). In her research, Romainville studied the granting of building permits in Brussels during the 2000s to show, inter alia, how the share of financial capital in housing production has increased, so that two-thirds of active developers had a connection to an economic sector other than real estate. Her research provided metrics to assess the extent to which those developers engaged in housing production in one major city are investing capital derived from their financial activities. Her approach to tracing capital to its source has been an important contribution to the methodological toolkit for assessing the impact of financialisation.

The empirical focus of this paper is a little different from Romainville's, as it is lodged at the national rather than the local level. It is concerned more with capital flows into and out of the production process, and the interests of actors such as shareholders in large housebuilding companies in the UK. Along with ownership of and access to land, these processes are a crucial launching-point for the financialisation of housing. Building on earlier analysis (Archer and Cole 2016), we examine the financial activities and performance of major housebuilding firms and show how outputs and levels of profitability and dividends have changed since 2005. This study is pitched at a 'meso'-level of analysis (van der Zwan 2014), concerned with institutional behaviour (Jacobs and Manzi 2019) and the use of particular 'technologies' such as financial metrics and accounting (Froud et al. 2000), rather than with either global capital flows, at the macro-level, or the financialisation of everyday life, at the micro-level.

\section{The changing shape of the UK housebuilding sector}

The recent financial and operational performance of large UK housebuilding firms should be set within the context of long-term structural changes in the sector. The development of large housebuilders in the form of public limited companies (PLCs)_-giving them greater access to development finance and enabling them to exert more power in land markets- has been crucial to this process. In 1980, there were over 10,000 small and medium 
enterprise (SME) housebuilders active in Great Britain, building 57\% of all new housing; by 2014 , this had dropped to 3000 SME builders delivering just $27 \%$ of all new dwellings (Lyons 2014).

Mirroring this shrinkage at the bottom of the market has been a concentration of market share at the top. Welling's (2006) examination of market shares in the sector showed that the biggest ten private housebuilders produced $28 \%$ of new national supply in 1980 . By 2015, the biggest ten housebuilding firms were producing $47 \%$ all new homes (Archer and Cole 2016). The process of consolidation and merger among the major companies has not always led to an increase in production. The output of the merged firms has often fallen, compared to the combined output of those firms beforehand (Griffiths 2011).

This concentration in market share at the top is a familiar aspect of corporate change. The reason why this is especially important in the housebuilding sector is its direct link to the achievement of public policy goals-notably increasing new housing supply. Housing policies and housing subsidies from the UK government have tended to focus on housing demand over the past thirty years or so, epitomised by the increasing reliance on Housing Benefit to help those in the social and private rented sector meet their housing costs (Cooke and Davies 2014).

There has been sporadic recognition of the supply problem in UK housing. The 'Barker review' of housing supply in 2004, which was commissioned by the UK Treasury, argued for the construction of an additional 70,000-120,000 dwellings a year in order to depress the increase in housing unaffordability (Barker 2004). This analysis was revisited ten years later (Home Builders Federation 2014) when it was suggested that the additional shortfall in the UK that had accrued during this period (which included the GFC) amounted to 953,000 homes. Nevertheless, the reliance on demand-centred subsidies, primarily through Housing Benefit and the new Universal Credit system, prevailed. The emphasis shifted towards housing supply under the Theresa May government of 2017-19. This included setting an annual target for the production of new dwellings, rising to 300,000 by 2022 . The UK government has recognised the risks of over-reliance on the small number of large firms that exert a powerful influence on overall supply (MHCLG 2017). This prompted some initiatives intended to revive the ailing SME housebuilding sector (HM Government 2015; MHCLG 2016) to 'rebalance' the industry. This renewed focus on housing supply has therefore drawn attention to recent trends in housing output, especially among larger housebuilders.

\section{The response of major UK housebuilders to the GFC}

The GFC had an immediate and dramatic effect on housebuilding in the UK, as in many other countries. Output by the largest nine UK housebuilders fell from 70,000 in 2007 to 45,000 in 2010. The views of developers about the process of recovery from this low point have been covered in Payne's research (Payne 2015, 2019), drawing on interviews with Chief Executives, Managing Directors and Land Directors from twenty three major builders in the UK. The respondents provided a legitimation of the business strategies their companies have followed since 2008. Payne identifies three distinct phases in their response to the GFC: investment, recovery and growth.

In the first phase, developers sought to restore some economic and fiscal balance following the shockwaves of GFC by facing down debt. Housebuilders claimed that they were adopting a more cautious and diligent approach to investment than before the GFC, 
when volume output had been the primary driver of business activity (Payne 2015). Most housebuilders found themselves highly geared as a result of pre-recession lending and so focused on generating cash to reinvest into their businesses-partly through rights issues and building out existing sites at better margins-rather making returns to shareholders. The investment phase was therefore characterised as a period when large housebuilders diligently used conventional business strategies to secure cash returns and secure higher margins, in order to recover their position. This recovery was then followed by the growth stage, where land acquired since the GFC was developed predominantly where it could deliver better margins and return on capital. It was also at this point that the government introduced the Help to Buy programme, providing equity loans to households so they could afford to access mortgage finance for new housing (National Audit Office 2019). The programme enabled builders to commit more confidently to construction programmes, reduce their reliance on inducements for purchasers, better predict future cash flows, and maximise land values to secure more development sites.

Payne found that as some housebuilders moved into the growth phase and they began opening more outlets and increasing capacity and output. However, respondents suggested that this move back to growth had been hampered by 'constraints' (Payne 2019, p. 12), such as planning delays and skills and materials shortages. Housebuilders continued to take refuge in conventional strategies to navigate their way through the recovery and invested their capital in land and development in more familiar and stable housing markets, to maintain or improve margins. Housebuilders therefore drew on existing organisational routines and repertoires in their response to the GFC, with government support through Help to Buy providing a more secure economic environment for investment. Their strategies focused on achieving more efficient returns on capital rather than radically changing the volume of output.

The picture that emerges from this analysis is of an industry making repairs to the damage caused by the GFC, moving ahead with cautious reinvestment, helped along by Help to Buy, and then constrained from further growth by factors such as land supply, capacity constraints and what was described as an 'unresponsive' planning system. The industry, sometimes criticised for a lack of innovation (Ball 1999), relied on established practices to generate returns through increasing margin rather than output. This analysis, reproducing an account 'from within' about the nature of the housebuilder response to the GFC, makes little or no reference to major changes in financial performance and priorities. This elite narrative is directed towards internal institutional changes, capacity and policy constraints, such as the onerous planning regime, rather than the financial environment in which the companies operated. Their account therefore offers a partial picture at best, as it neglects the impact of capital flows into, and outflows from, the sector. Far more dramatic changes were taking place here than this 'institutional recovery' paradigm suggests. Before taking account of these wider trends, we outline the methods used in our analysis of the financial performance of major housebuilders since 2006.

\section{Methods for the analysis of financial and operational data}

This study draws on information provided in the annual reports and accounts of the UK's largest nine private housebuilders (in terms of their revenue). It has captured and analysed data from 126 annual financial reports. These reports cover the pre- and post-GFC period from 2005 to 2017, enabling changes in financial and operational 
performance to be tracked longitudinally. Data have been organised in a form which makes analysis possible for both individual firms and in aggregate. This is important given the large market share of these firms and their collective role in shaping the market for new housing nationally.

International accounting standards ensure that the financial data provided by each housebuilding firm is in a standard form. The International Financial Reporting Standards (IFRS) do not guarantee that financial figures for two firms are referring to identical financial activities, nor do they assure total transparency in terms of underlying activities (Jeanjean and Stolowy 2008). Nonetheless, they are a mandatory set of reporting standards that offer a means for comparison and aggregation of financial information across firms.

This paper presents analysis of key financial and operational data for these firms, principally concerning their revenues, profit before tax (before exceptional items), yearend profit, dividends paid, proceeds from the issue of new share capital, new dwelling completions and average sales prices. The decision to look at profit before tax before exceptional items was taken on the grounds that this better reflects the normal business activities of firms without, for instance, factoring in the yearly adjustments in the estimated value of land and other assets. To ensure this measure is not taken as the sole indicator of profitability, changes in year-end profit were also assessed. This measure does factor in exceptional items, levels of taxation and so on. Wherever possible, data have been drawn from segmental analysis in the financial accounts, in order to isolate UK activity only and that which is related purely to housebuilding rather than income and expenditure on other activities, such as commercial property construction or property investment more broadly. Furthermore, rather than use future dividend commitments in the narrative sections of the annual reports, we draw dividend information from the audited accounts, via the consolidated cashflow statements.

We have amalgamated the above data with information about the ten largest institutional shareholdings in each firm and the investors holding those shares (Financial Times 2017). To explore capital flows into and out of the UK's housing supply system in detail, we examine in more detail one of the largest shareholders in UK's major housebuilders, Norges Bank Investment Management (henceforth Norges). Our research focused on Norges as, at the time of study, they held shares in nearly all of the largest private housebuilders in the UK (eight out of the nine biggest firms). The selection of Norges was also a pragmatic decision, given their transparent approach to reporting investments, and difficulties in obtaining comparable information for other institutional investors and asset managers. Norges investments are open to analysis through publicly available data on all their holdings, which are updated each year. These holdings are categorised into three types: equities (such as shareholdings); real estate investments; and fixed-income investments (such as government or corporate bonds). Analysis of these holdings in 2016, and how they changed from 2015, made it possible to identify new investments that could be providing new capital for housing production.

It is important to note that Norges may not be representative of the broader class of large investors in UK housebuilders, in terms of the extent of new capital it provides for housing production on an annual basis. However, it is difficult to assess this, given the lack of data on holdings by other investors and asset managers. To assess Norges' returns in dividends from UK housebuilders, alongside the investments it made in broader housing production activity, all of its equity and fixed-income investments in 2015 and 2016 were analysed (Norges Bank Investment Management 2017). The case 


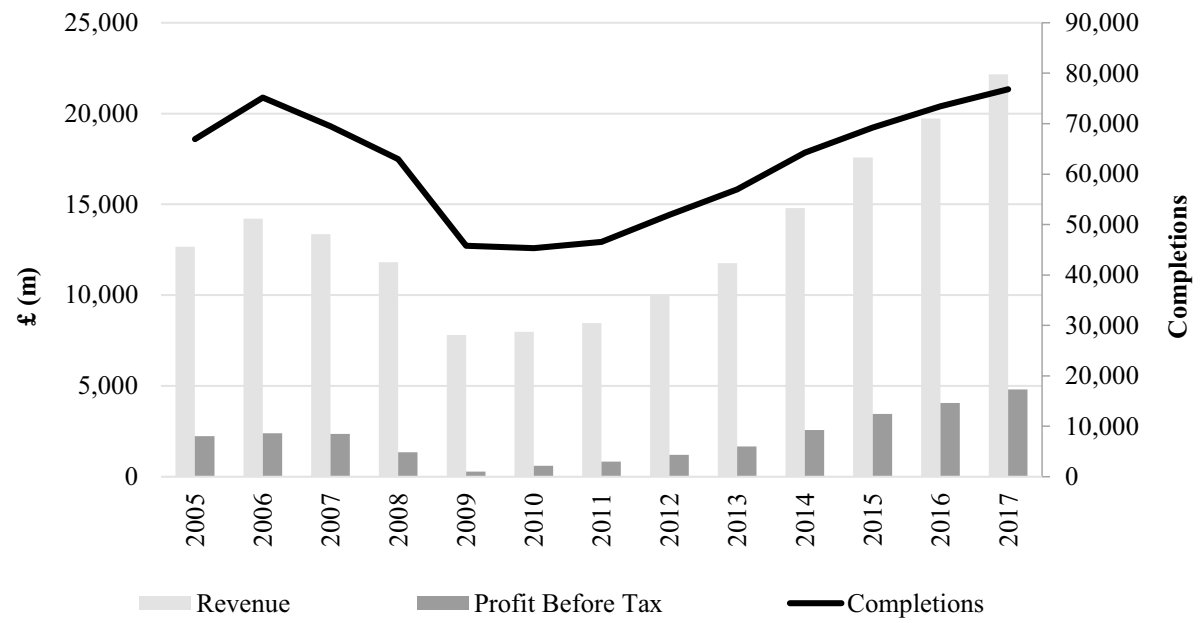

Fig. 1 Revenue, profit before tax and completions for the nine largest UK housebuilders (2005-2017). Source: Housebuilder accounts (2005-2017)

study provides a more nuanced assessment of the complexity of capital flows into and out of the UK housing system.

\section{Trends in supply, revenue and profit among the largest UK housebuilders}

Previous research (Archer and Cole 2014, 2016) has provided a close inspection of the financial accounts of the largest private housebuilders in the UK. This examines changes between 2008 and 2015 in profit levels, housing completions, changes in the geographical distribution of new housing and in the use of surpluses by the largest nine UK housebuilders. Clear patterns emerged in this work, suggesting that revenues, profits and dividends were expanding at a disproportionately faster rate than the output of new housing (Archer and Cole, 2016). For the purposes of this article, the analysis has been extended in terms of both the financial measures analysed and the time frame covered.

The timeline for the current analysis has been taken back to 2005, before the GFC, and run forward to 2017. Figure 1 shows the total completions, revenue and profit before tax (PBT) of the largest nine housebuilders for this period. The impact of the GFC is clearly evident in the period 2007 to 2011, with 2009 representing the nadir in terms of revenue and PBT. The 'institutional recovery' narrative of the developers suggests that it took the industry several years to build back their finances after the devastation caused by the GFC and that this is reflected in modest year-on-year increases in output. This rationale is not, however, a comprehensive, or indeed accurate, picture of actual trends.

Figure 2 shows that between 2010 and 2017, the revenue and PBT of the nine largest housebuilders increased at a much more rapid annual rate than their housing completions. During this period, the output of new homes grew by $\mathbf{7 0}$ per cent, from 45,000 units in 2010 to 76,000 in 2017. But over the same period revenues increased by 178 per cent, while PBT rose by $\mathbf{7 0 3}$ per cent: from $£ 600 \mathrm{~m}$ to $£ 4$. 8 bn. Increasing profitability was seen 


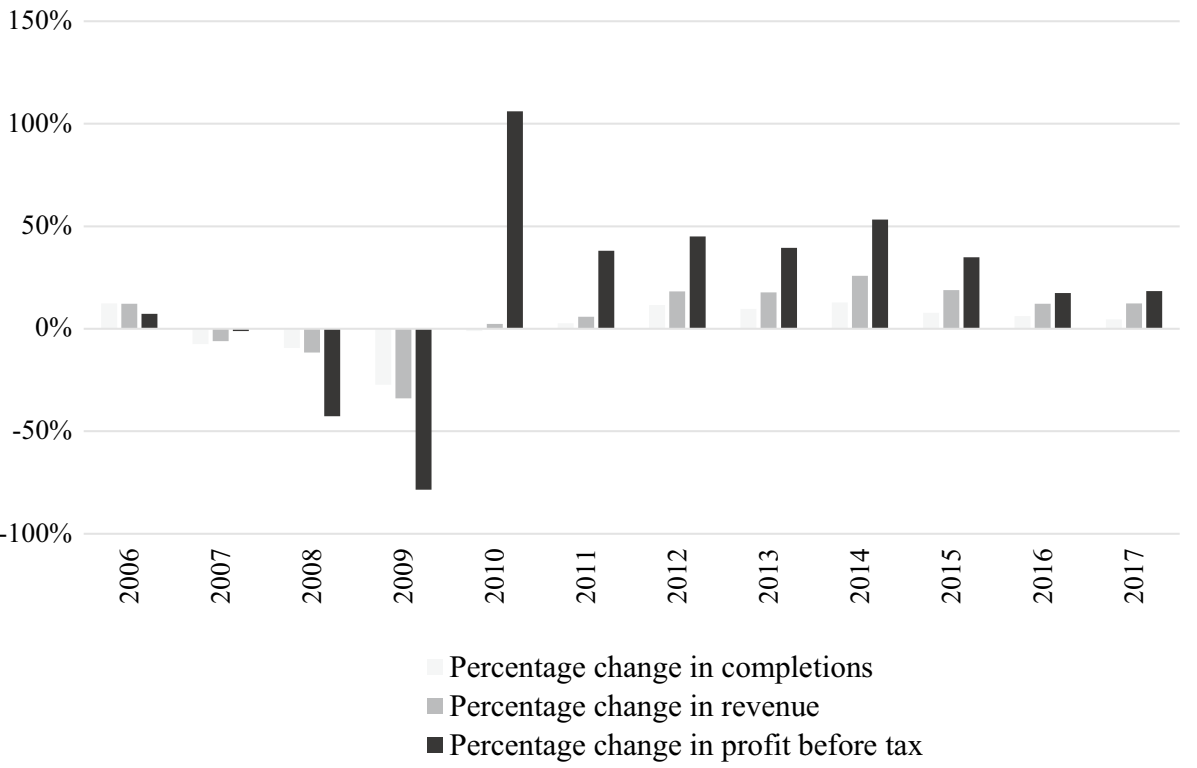

Fig. 2 Year-on-year changes 'in financial and operational measures for the biggest nine UK housebuilders (2006-2017). Note Yearly change is shown from 2006 onwards, using 2005 figures as the basis for the first annual change. Source: Housebuilder accounts (2005-2017)

by some firms as the successful outcome of 'prioritising margin over volume' (Taylor Wimpey 2011, p. 1).

Comparisons with the pre-GFC era bring into question the assumption that this was simply a period of 'recovery'. By 2014, profitability for these nine firms had almost returned to the pre-GFC peak of 2006. By 2015, PBT stood some 45\% higher than pre-GFC levels. By 2017, these housebuilding firms were generating over $100 \%$ more profit than they were before the financial crash. This was more than a 'recovery'; it was a feast after the fast, and one which had taken profitmaking among large UK housebuilders to historically unprecedented levels. While the level of profitmaking had doubled in this period, in terms of housing supply the largest housebuilders developed only 1600 more homes in 2017 compared to 2006, an increase of just two percent.

In the period between 2010 and 2017, firms decided to stretch the gap between unit costs and the sales price per unit, in pursuit of higher profitability per housing completion. Of course, profitability might have been pursued by maintaining profit margins and rapidly increasing production, but this strategy was not favoured. As we have seen, the tendency to focus on margins was noted by developers themselves as they made strategic choices after the GFC. What is, however, absent from their own narrative is any recognition of the scale of the divergence between trends in output, revenue and profit. The developers' discourse is one that depicts them as licking their wounds after the GFC, and duly playing safe in their subsequent investments, while acquiring land at attractive rates. In fact, the modest increases in output since 2010 mask a much greater transformation in the levels of profitability achieved. Larger housebuilders were not, according to these figures, struggling to maintain their margins - they were increasing them significantly over this period. 
Table 1 Ratio of completions to profit before tax (PBT) for the nine largest UK housebuilders (2005-2017)

\begin{tabular}{ll}
\hline Year & $\begin{array}{l}\text { Ratio of } \\
\text { completions to } \\
\text { PBT }\end{array}$ \\
\hline 2005 & $1: £ 33,313$ \\
2006 & $1: £ 31,818$ \\
2007 & $1: £ 34,033$ \\
2008 & $1: £ 21,545$ \\
2009 & $1: £ 6,358$ \\
2010 & $1: £ 13,242$ \\
2011 & $1: £ 17,803$ \\
2012 & $1: £ 23,138$ \\
2013 & $1: £ 29,419$ \\
2014 & $1: £ 39,999$ \\
2015 & $1: £ 50,091$ \\
2016 & $1: £ 55,427$ \\
2017 & $1: £ 62,702$ \\
\hline
\end{tabular}

\section{Profitability, Dividends and Value Extraction}

As Figs. 1 and 2 show, the profits of large housebuilders increased markedly from 2010, although the rate of this growth year on year has slowed since 2014. One measure, however, has continued to grow every year since the GFC; that is the ratio of PBT to housing completions. This is essentially a measure of return on investment and is a signal of how far major housebuilders have shifted their business strategy to more financialised models. In 2008, the ratio of profit to each new dwelling completed was $£ 21,545$ - that is, for every house built $£ 21,545$ of profit before tax was derived. This ratio then slumped in 2009 , in the midst of the GFC, but has increased consistently year on year. In 2017, for every unit developed $£ 62,702$ of PBT was created (Table 1). This trend challenges the narrative of housebuilders that they have been slowly recovering before a return to growth, Table 1 reveals these increases in the ratio of PBT per unit between 2005 and 2017, showing how it nearly doubled over that period.

The above trends, in part, reflect the growth in end sale prices of the new homes built. In the perennial discussions about the causes of rising house prices in England, reference is made to a range of contributory supply and demand factors, but the increasing profit 'take' per new home is rarely included in these discussions. Figure 3 shows the average sale price of new homes built by the largest housebuilders between 2005 and 2017. In 2005, new homes built by Barratts, for example, were $12 \%$ above the average national house price. After the GFC slump, price growth returned, so that by 2013 Barratt's units were selling - on average - at a 14\% higher price than the national average. By 2017, Barratt's sales prices were $26 \%$ above the average UK house price. In absolute terms, new homes completed by Barratts were nearly $£ 49 \mathrm{k}$ more than the average price of a UK home in 2017. The increasing level of profitability per housing unit produced is therefore reflected in higher average sale prices of new homes.

The increases in revenue and profitability since 2010 have continued well beyond a point where it can be seen as simply compensating for any legacy losses stemming from the GFC, or as prudently insulating the business from future shocks. In practice, 


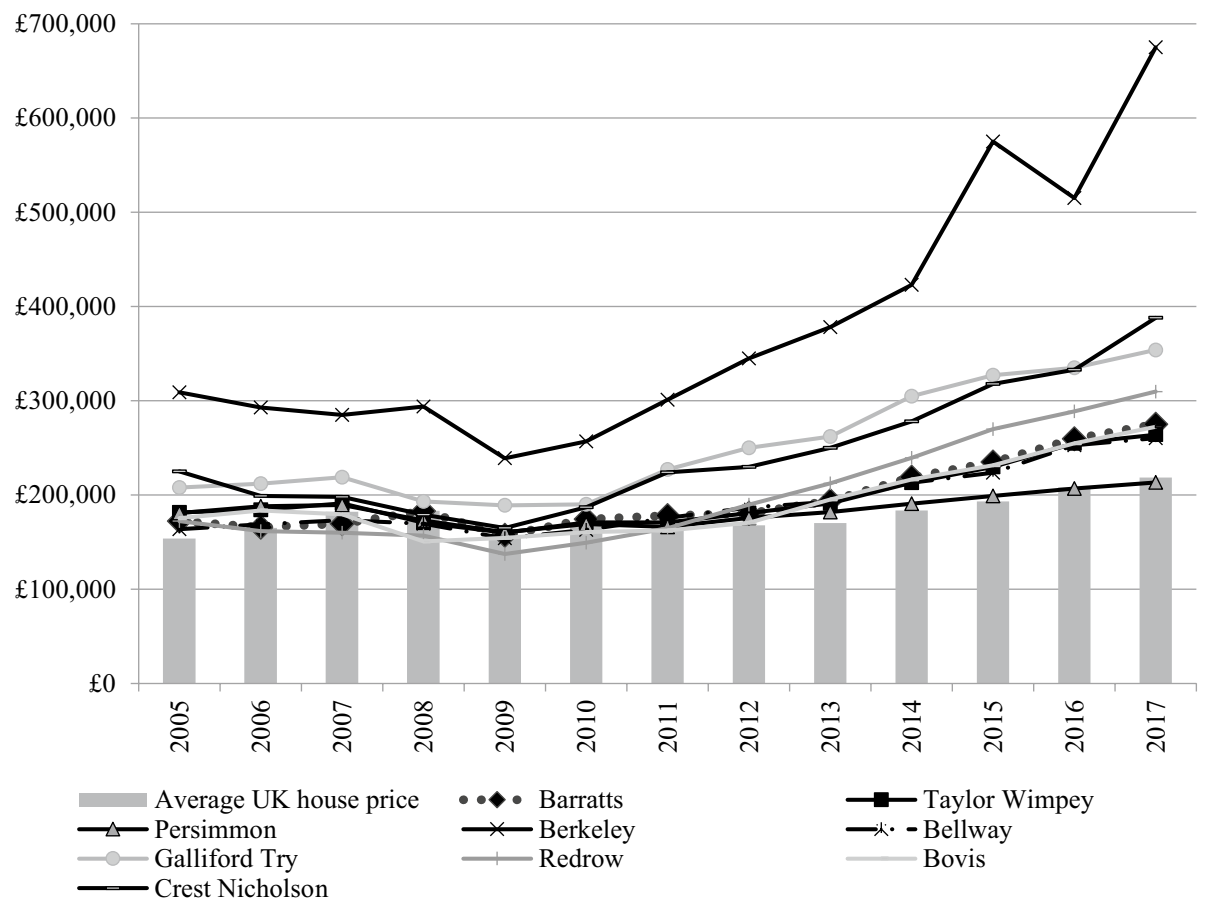

Fig. 3 Average sale prices for the biggest nine UK housebuilders and the average UK house price (20052017). Sources: Housebuilder accounts (2005-2017) and Land Registry House Price Index (Average Price All Properties-2005-2017)

this has resulted in significant gains for both shareholders and executives. On rare occasions, shareholders may kick back against extreme outcomes for incentivising company executives. One such occasion was the disclosure in December 2017 of the bonus payments made to senior executives at the housebuilders Persimmon, in which the Chief Executive, Jeff Fairburn, stood to gain around $£ 120$ million, the Finance Director $£ 77$ million and the Managing Director $£ 38$ million. Financial sector interests represented on the board were concerned that the scale of the pay deals, and the consequent press coverage, would wreak reputational damage. Euan Stirling, Head of Stewardship at the major investor Aberdeen Standard, which owned a 2.3\% stake in Persimmon at the time, disapproved of the deal, saying that 'regardless of any moral or societal duties, company directors have a legal responsibility to act in the best long-term interests of the company that employs them' (The Independent 2018). The Persimmon deal was therefore presented as an anomaly or an outlier, the unacceptable face of finance capitalism, rather than just one end of a spectrum in the trend of rapidly inflating pay outs for senior executives across the housebuilding sector.

Trends in other forms of capital outflow reveal the growing influence of financial interests in UK housing production. Returns to shareholders through dividends have reached unprecedented levels in recent times, as shown in Fig. 4. In the years leading up to 2009-depicted as a 'risk taking' boom by proponents of the institutional recovery narrative-dividends from the largest nine housebuilders had followed a fairly steady path, at below $£ 400$ million per year. This peaked in 2008 at the aggregate figure of 


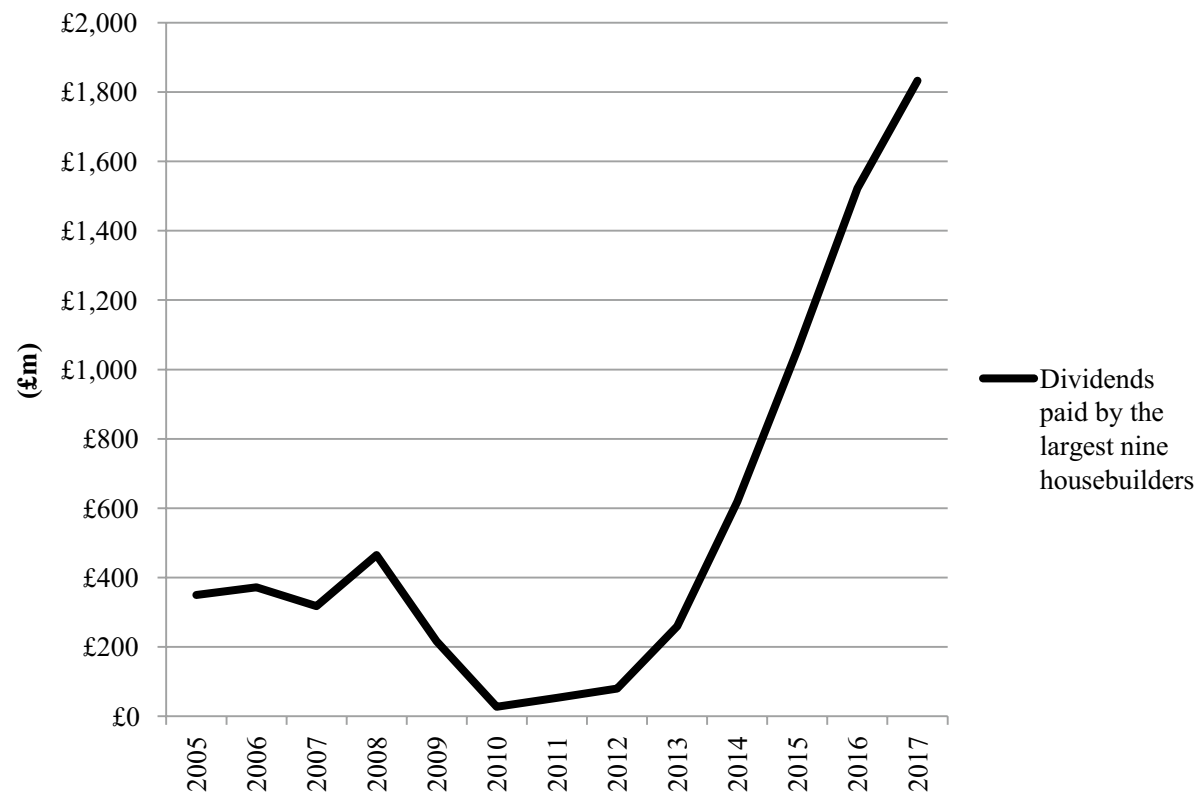

Fig. 4 Total dividends paid per year by the nine largest UK housebuilders (2005-2017). Source: Housebuilder accounts (2005-2017)

$£ 464 \mathrm{~m}$. The figure for 2017 , by contrast, stood at $£ 1.8 \mathrm{bn}$, dwarfing the levels of dividends paid in the years leading up to the GFC.

This marked growth in dividend payments has increased as a proportion of annual profits, not just in terms of absolute value. For the nine biggest housebuilders, dividend payments were running at approximately twenty per cent of year-end profits in 2005 and 2006, rising to just over thirty per cent in 2007. During the GFC dividends continued to be paid, but on year-end losses. As housebuilding firms returned to profitability this ratio increased sharply, rising from seven per cent of year-end profits in 2010 to $39 \%$ in 2015. This figure is higher than that for the pre-GFC 'boom years', and the percentage continued to move upwards. In 2017 dividends amounted to fully $50 \%$ of year-end profit (Fig. 5).

One response to these figures might be that distributing surpluses in this manner is not an inherent problem or a morally dubious activity. The funds derived by shareholders from dividends may, in time, be reinvested back into the economy in productive ways, perhaps even supporting further housebuilding, so the argument runs. One way to test this claim is to examine the activities of shareholders in the largest housebuilding firms, i.e. those who have benefited most from this step-change in dividend payments. Using data provided by the Financial Times (2017), it was possible to identify the ten investors with the largest shareholdings in the UK's biggest housebuilders. This analysis revealed that the largest investors held shares in multiple housebuilding firms. Indeed, three investment managers (Legal and General Investment Management, Norges Investment Management, Vanguard Group) were among in the largest shareholders in eight of the nine biggest housebuilders. Through this, these organisations can exert significant influence not just on one housebuilding firm and its financial decisions, but on the industry at large. They could assert their demand for maximising shareholder value in eight different board rooms, knowing 


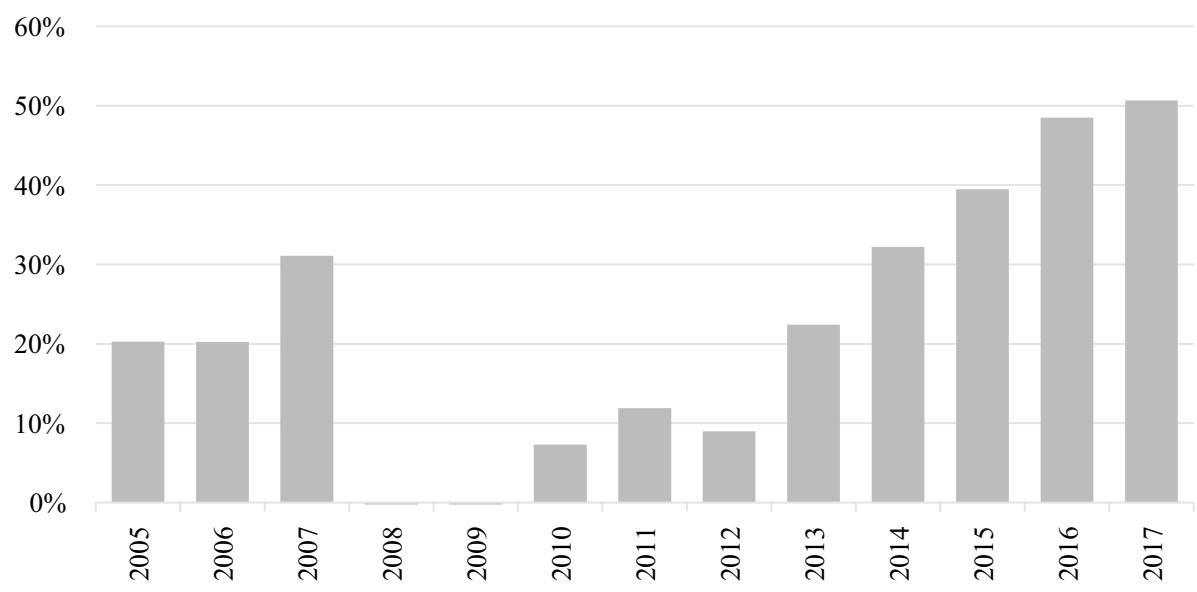

Dividend as a percentage of yearly profit

Fig. 5 Dividends paid as a percentage of profits for the year, for the nine largest UK housebuilders (20052017). Source: Housebuilder accounts (2005-2017)

what the ramifications of selling their shares would be for wider confidence in the firm and its stock price.

The global nature of financial interest in UK housebuilders is indicated by the fact that many of the largest shareholders were not UK investment managers. For instance, an estimated $71 \%$ of all shares in Taylor Wimpey were, at the time of data collection, held by investment managers based overseas. The surpluses created by housebuilders, and then paid out in dividends, are likely to flow well beyond UK shores, and potentially be reinvested outside of the UK's housing market. This makes it challenging to assess the ultimate impact of such large-scale distribution of surpluses on domestic housing production. It also poses serious questions about the prospects for decisive intervention in these processes by any national government that is seeking to ramp up housing supply.

The nature of the relationship between UK housebuilders and their shareholders, and the implications of this for capital flows, can perhaps be understood better by focusing not on the housebuilding firm, but on individual shareholders. As we have noted, shareholder influence is largely absent from the 'institutional recovery' narrative provided by executives in their accounts of post-GFC corporate performance, but it is a key factor in the system of housing production overall.

\section{Tracing capital flows: The Case of Norges Bank Investment Management}

The above analysis underlines the scale and implications of large extractions of capital from the UK housing production system-by a relatively small set of financial actors. But it remains unclear whether shareholders are simply net extractors of value or whether they exist in a more symbiotic relationship with housebuilders to create value. It might be argued, for example, that capital flows to investors - in the form of dividends - are a worthwhile quid pro quo for capital investments made by those investors in other areas of the 
housing system. Indeed, if these capital flows from investors are equal to (or greater than) the capital flows back to them (in the form of dividends), then it might be claimed that such dividends are an integral part of the financing of new housing supply. Further analysis was therefore required to see if major shareholders - as beneficiaries of large increases in dividends - were imparting additional capital back into the housing system.

Tracing capital flows is far from straightforward, as it requires delving into the highly complex circuitry of modern, global finance, where obfuscation is part of its raison d'etre (Kay 2015). Nonetheless, where information about investments made can be combined with information about dividend returned, it is possible to trace capital flows between individual investors and UK housebuilders. In examining such data, only those investments which impart new capital for housing production should be classed as a capital inflow. When an individual or institution purchases shares in a company that are already in circulation, it does not impart new capital into the firm; it is merely trading with another investor. Only when a shareholder purchases new shares (for instance, through an Initial Public Offering issued by a housebuilder) can this be considered new capital for housing production. Other investments may also provide new capital; for instance, through the purchase of government bonds which are then invested in housing-related activity, or by providing loans and other debt finance directly to the housebuilding firm.

Using this understanding of capital flows, we have sought to understand the role and flows in one specific case, Norges Bank Investment Management (henceforth Norges), which is the asset management unit of the Norwegian central bank. At the time of study, Norges had major shareholdings in eight of the nine largest UK housebuilders.

\subsection{Capital inflows-investments by Norges to support UK housebuilding}

Analysis of Norges real estate holdings in 2016 shows they focused largely on retail, logistics and office sites. This followed the strategic decision not to invest in the residential and hotel sectors, ${ }^{2}$ and hence, these investments were unlikely to have directly facilitated the production of housing in the UK. However, Norges' fixed-income investments did provide capital to support such activity in the year of study. The organisation acquired nearly $£ 33$ million of UK government bonds in PRS Finance PLC, which has the aim of increasing 'the supply of new, purpose built and professionally managed private rented sector homes' ${ }^{3}$ In addition to this, Norges made one equity investment which might be classed as providing new capital for housebuilding. Norges purchased approximately £12.5 million worth of new shares in McCarthy and Stone, a large builder ${ }^{4}$ specialising in retirement housing. These shares-purchased as part of an Initial Public Offering-would, it was hoped, "provide flexibility for further investment in land and building" (McCarthy and Stone 2015, p.13). Other investments to support the production of housing were more difficult to trace. Norges held other relevant bonds, acquired in previous years, but direct investments in 2016 amounted to a capital inflow to the UK housing production system of just over $£ 45$ million.

\footnotetext{
${ }^{2}$ See https://www.nbim.no/contentassets/e16eb87c37294c0fabcca82951f89ac0/real-estate-investment s-2017---government-pension-fund-global.pdf.

3 See http://www.venn-partners.com/prs/.

4 McCarthy and Stone had an operating profit of $£ 96.2 \mathrm{~m}$ and a profit margin of 15 per cent in 2017.
} 


\subsection{Capital outflows-capital extracted by Norges from UK housebuilding}

Norges made substantial capital returns on their equity investments in 2016. Its shareholdings in the biggest UK housebuilders generated over $£ 35$ million in dividends in this year. The biggest capital gains, however, were made in relation to increasing share prices. Changes in Norges' equity holdings in the UK's biggest housebuilders generated financial gains in the region of $£ 122$ million in 2016. This figure relates simply to the increased value of shares arising from movements in share price between March 2015 and March 2016. Norges reported reduced market values for its shareholdings in certain housebuilders in 2016, due to selling-off of shares to realise capital returns. For instance, Norges reduced its stake in Berkeley Group in 2016 and, even in the context of a falling share price, this realised a return of between $£ 18-22$ million from this sale of shares (Norges 2017).

Hence, the $£ 45 \mathrm{~m}$ of new capital offered by Norges to support housing production was therefore eclipsed by the capital flows back to them from dividends and share price gains, which total $£ 158 \mathrm{~m}$. The market value of Norges’ shares in UK housebuilders in December 2015 was $£ 664 \mathrm{~m}$. By 2017 this had increased to $£ 863 \mathrm{~m}$ (Norges 2017).

There is no a priori reason to presume that the practices of Norges are untypical in the sector. Some of the largest shareholders in UK housebuilders are extracting much more capital out of housing production than they are putting back into it. Ownership of shares in housebuilding companies provides a means for these institutions to shape strategies over the distribution of surpluses and to undertake activities which increase the underlying share price. Reinvestment in productive activity is given less priority. This analysis also reveals a perverse circularity in the relationship between these financial interests and the government. The government raises finance from firms such as Norges-through government bonds which have the aim of increasing investment in affordable housing. At the same time, Norges and other investors pursue increased returns on equity investments in housebuilding firms arising from increasing profit margins and average sales prices, which exacerbate rather than mitigate affordability problems.

It should be acknowledged that major shareholders in private housebuilders are not all adopting the same strategies, as some are taking on a more proactive role in the housing market. For instance, Legal and General (Investment Management) receives significant returns from shareholdings in eight of the biggest UK housebuilders, but the Legal and General group also contains subsidiaries which are competitor housebuilders, ${ }^{5}$ as the organisation makes investments in facilities for modular construction of housing ${ }^{6}$ and partnerships to build and rent for specific markets. However, only a few shareholders in the UK have so far gone down the route of direct housing provision, and there are examples of such a shift taking place elsewhere in Europe (Wijburg et al. 2018). Overall, tracing capital flows prompts questions about the wider picture of leakage from the UK housing market, and the case of Norges exemplifies how the financing of private housebuilding is more about creating shareholder value than increasing housing supply. Any downstream economic benefits emanating from increased dividends are likely to be very diffuse, at best.

\footnotetext{
5 See https://www.landghomes.com/.

6 See https://www.legalandgeneral.com/modular/.
} 


\section{Discussion: financialisation and the post-GFC Recovery}

In assessing the results shown above, one might be open to an accusation of faux naivete in confessing surprise. Housebuilders are private companies, and the property and finance sectors have forever been closely intertwined; and they are profit seeking bodies, not social enterprises or charitable institutions. What would one expect them to do? However, we would suggest that the extent to which the strategy, operation and business planning of large housebuilders have been influenced by financialised priorities and narratives since 2008 is now qualitatively different. This is reflected in the figures on dividends and the ratio of dividends to profit, showing the scale of capital outflows running at levels that are historically unprecedented.

One distinctive aspect of financialisation is the extent to which what is produced by companies becomes less important than how the asset or service can be utilised as a lever for increased borrowing, investment and growth maximisation through debt finance (Aalbers 2015; Van Loon and Aalbers 2017; Gamble 2014). This trend is especially notable when what is being produced (or, indeed, not produced) - housing — is infused with state support in various ways and where housing supply is a key public policy concern. The financial performance of major housebuilders indicates how shareholder value has become more prominent in dictating how firms ought to be run, for short-term returns rather than for longer-term output growth - that is, building homes. As Mazzucato has suggested:

...far from being a lodestar of corporate management, maximising shareholder value turned into a catalyst for a set of mutually reinforcing trends which played up short-termism while downplaying the long-term view and a broader interpretation of whom the corporation should benefit. (Mazzucato 2018, pp. 166-7).

Under this process, executives are incentivised to deliver capital growth and higher dividends ahead of other objectives, such as productivity gains or increased output (Froud et al. 2006; Roberts et al. 2006). As a result, firms come under increasing pressure to boost capital flows to the financial sector through interest payments, dividend payouts and share buy-backs (Lazonick and O'Sullivan 2000; Lazonick 2014). Longterm investment, organisational development and product innovation take second place to short-term profit, outsourcing and share prices (Aalbers 2017a). Whilst not the focus of this paper, these processes may have been assisted by the consolidation in the industry noted in section three. As the largest housebuilders have taken more market share, and mergers have tended to result in a net reduction in output, one might question if the move towards an oligopolistic model (Griffiths 2011) facilitates the financialisation process. As noted, nearly all the major shareholders in the biggest housebuilders have shares in several of those housebuilding firms. And given that these firms are responsible for such a significant proportion of national supply, the role of shareholders in shaping new housing production has perhaps never been greater.

The increasing priority given to shareholder value and the dominance of 'impatient' capital (Crotty 2003) are not, of course, idiosyncratic, post-GFC developments. As Lee et al (2009, pp. 727-8) suggest:

...financialisation is hardly a new phenomenon in circuits of capital. What is perhaps relatively new is the extent to which finance has found its way into most, if not all, nooks and crannies of social life. 
What our analysis of major UK housebuilders adds to a longer-term perspective on the impact of financialisation is threefold. First, it provides empirical confirmation that the shock of GFC did not have a longer-term chastening effect, inhibiting the incursions of finance capital into new territory. Indeed, it was quite the reverse, since it created the opportunity for housebuilders to reformulate their business models, and then ramp up returns to shareholders. Second, it shows how housing production has become a prime site for capture by finance capital. Third, it helps to explain how the recovery of larger UK housebuilders since 2010 has only had a limited impact on housing output: capital has been generated, but much of it has moved elsewhere, and supply has consistently fallen far short of government targets, despite the introduction of additional inducements, such as Help to Buy.

In terms of housing output, the continuing trend of historically low interest rates in the UK economy since 2010 might have been expected to encourage large-scale borrowing for investment, once the financial wounds of the GFC had started to heal. This has not happened. Instead, the trend to maximise shareholder value has inhibited new investment, as the hurdle rate-the return on investment below which a company will not pursue an investment opportunity-is set higher. The cost of debt financing has been extremely low in recent years, but there has been an increasing margin between the cost of capital and expected returns from investment, especially if there are easier and potentially more lucrative alternatives to explore, such as share repurchases (Mazzacuto 2018: p. 176). This may help to explain developer caution to build moredue less to the uncertain state of housing markets or the adoption of risk-averse business practices, and more to the weight of shareholder expectations about what margins could and should be secured. This period of cheaper borrowing has not led to an increase in the level of investment in new construction that might have otherwise been anticipated.

Our analysis takes us into different territory about trends in the UK housebuilding sector than that covered by the institutional recovery narrative (Payne 2019), which makes only oblique reference to the need to seek new ways of maximising shareholder dividends and focuses instead on constraints such as the planning system. Publicly, the purpose of the organisations remains ostensibly unchanged, using cautious reinvestment and judicious selection of sites and developments to extend activity. The major housebuilders in the UK often prefer to hold on to their name through institutional restructures, partly to convey a sense of stability and trust and display their long-standing reputational assets to make it 'as safe as houses'. This had happened to many UK building societies after deregulation in the mid-1980s (Martin and Turner 2000). Many of the larger housebuilders still hold on to a 'family firm' motif-Taylor Wimpey, Barratts, Persimmon - rather than a more corporate name. The image that is cultivated is that they are just like other, more humble builders, just bigger. Hulse (2019) describes a similar process at play in the discursive reframing of the private landlord. In fact, our examination of the recent financial performance of major housebuilders shows an increasing divergence in patterns of ownership, business priorities and financial performance-not just from SME enterprises in the sector but also from the position they themselves held before the GFC. To explain housebuilders behaviour since the GFC we suggest more diligent consideration of the financial processes underpinning their operations. This reveals that the recovery of housebuilders was not the cautious, constrained variety argued by some (Payne 2015), but a financialised recovery focused on maximising profit margins and returns to shareholders. 


\section{Conclusion}

The analysis in this paper reveals striking increases in the profit per unit derived by the largest UK housebuilding companies in recent years, along with a historically unprecedented rise in their dividend payments. Our focus on organisational strategies, financial performance and the growing influence of shareholder value contrasts with the focus of others who look outward to explain the factors associated with housebuilder behaviour and the sluggishness of housing supply. The organisational focus adopted in this paper reveals the pervasiveness of global finance, and the scale of capital extracted through the housing production process. Huge financial sums are flowing out of the UK housing system, but they are largely invisible in housebuilders' own narrative about their 'recovery' since 2007/8. The push and pull of capital flows is largely subterranean, beneath the public gaze and policy discourse. Occasionally, an extreme case of corporate largesse is revealed, as in the case of Persimmon Homes, but this is then seen as the exception not the rule.

The self-serving complexities of global finance (Kay 2015) present a formidable challenge to anybody attempting to 'follow the money' and track the distribution of asset value, borrowing and debt in any economic sector. The extent of shareholder gain in the UK housebuilding industry has been transformed in the past ten years, but this is not evident when set against the incremental changes in new dwellings built year-on-year. We would readily acknowledge that this paper has only scratched the surface of specifying how these interrelationships play out in practice. However, the relationship between housebuilding firms and financial investors can be more complex than how it is promoted. The public narrative emphasises how, at a time of austerity in public finances, investors are stepping in to provide much needed access to capital to get more houses built. In practice, it is a twoway process: the housebuilding sector helps to sustain and enrich financial organisations by proving a conduit for excess capital.

There is still a largely untouched research agenda here - there is ample scope to examine cross-national capital flows more closely, and to compare the financial strategies and positioning of different housebuilding firms and investors. Furthermore, there is merit in exploring how far housebuilders are introducing new financial products and services, how they exert influence in practice on government interventions and financial support. Analytical advancements may also be made in mapping the complex web of shareholdings and new vehicles for housing investment.

In this paper, certain assumptions have also been made about the elision between shareholder preference and executive action, and the extent to which there is a shared culture between different actors in the process - such as members of the Board and the executive team in major housebuilders. It would be instructive to examine this relationship empirically, but it is an arena unlikely to open itself up readily to independent inquiry. We should also be cautious at this stage about how far the detailed analysis in this paper is typical of wider trends when looking beyond the UK. Work is required to understand the consequences of consolidation in the housebuilding sectors in different countries (cf. Wissoker 2016). The process of financialisation is likely to take a different trajectory in different countries, even if the underlying process follows a similar pattern (Aalbers 2017b).

The challenge for research into the changing dynamics of the housebuilding sector is intensified by the fast-moving nature of the world of global finance. It is hardly an original insight to note that finance capital has a voracious and insatiable appetite for the new, for moving on to another sector which is seen as more amenable to asset capture and institutional transformation. Since the GFC, corporate finance has alighted on UK 
housebuilding companies, having depleted other possibilities as avenues for investment. It remains to be seen what we happen in the post-pandemic economy, and whether similar trends will emerge as happened after the GFC. The analysis in this paper suggests one should not assume that any stimulus to assist larger housebuilders - to remedy the foreseen fall in housing output as a result of the pandemic-will produce anything like the outcomes envisaged or hoped for by governments.

Funding The authors did not receive support from any organisation for the submitted work.

\section{Compliance with ethical standards}

Conflict of interest All authors declare that they have no conflict of interest.

Open Access This article is licensed under a Creative Commons Attribution 4.0 International License, which permits use, sharing, adaptation, distribution and reproduction in any medium or format, as long as you give appropriate credit to the original author(s) and the source, provide a link to the Creative Commons licence, and indicate if changes were made. The images or other third party material in this article are included in the article's Creative Commons licence, unless indicated otherwise in a credit line to the material. If material is not included in the article's Creative Commons licence and your intended use is not permitted by statutory regulation or exceeds the permitted use, you will need to obtain permission directly from the copyright holder. To view a copy of this licence, visit http://creativecommons.org/licenses/by/4.0/.

\section{References}

Aalbers, M. B. (2015). The potential for financialization. Dialogues in Human Geography, 5(2), 214-219.

Aalbers, M. B. (2016). The financialization of housing: A political economy approach. London: Routledge.

Aalbers, M. B. (2017). Corporate financialization. In D. Richardson, N. Castree, M. F. Goodchild, A. L. Kobayashi, \& R. Marston (Eds.), The international encyclopedia of geography: people, the earth, environment, and technology. Oxford: Wiley.

Aalbers, M. B. (2017). The variegated financialization of housing. International Journal of Urban and Regional Research, 41(4), 541-554.

Aalbers, M. B., \& Engelen, E. (2015). The political economy of the rise, fall, and rise again of securitization. Environment and Planning A, 47(8), 1597-1605.

Aalbers, M. B., Fernandez, R., \& Wijberg, G. (2020). The financialization of real estate. In P. Mader, D. Mertens, \& N. van der Zwan (Eds.), The Routledge international handbook of financialization. New York: Routledge.

Archer, T., \& Cole, I. (2014). Still not plannable? Housing supply and the changing structure of the housebuilding industry in the UK in 'austere' times. People, Place and Policy, 8(2), 97-112.

Archer, T., \& Cole, I. (2016). Profits before volume? Major housebuilders and the crisis of housing supply. Sheffield: Sheffield Hallam University.

Ashman, S., \& Fine, B. (2013). Neo-liberalism, varieties of capitalism and the shifting contours of South Africa's financial system. Transformation, 81(2), 144-178.

Ball, M. (1999). Chasing a Snail: Innovation and Housebuilding Firms' Strategies. Housing Studies, 14(1), 9-22.

Barker, K. (2004). Review of Housing Supply: Delivering Stability: Securing our Future Housing Needs. Retrieved 4 December 2020 from http://news.bbc.co.uk/nol/shared/bsp/hi/pdfs/17_03_04_barker_revie w.pdf.

Beswick, J., \& Penny, J. (2018). Demolishing the present to sell off the future? The emergence of 'financialized municipal entrepreneurialism' in London. International Journal of Urban and Regional Research, 42(4), 612-632.

Boddy, M. (1989). Financial deregulation and UK housing finance. Housing Studies, 4(2), 98-104.

Christophers, B. (2015). The limits to financialization. Dialogues in Human Geography, 5(2), 183-200. 
Cooke, G., \& Davies, B. (2014). Benefits to bricks: Mobilising local leadership to build homes and control the benefits bill. Retrieved 4 December 2019 from https://www.ippr.org/publications/benefits-to-brick s-mobilising-local-leadership-to-build-homes-and-control-the-benefits-bill.

Crotty, J. (2003). The neoliberal paradox: The impact of destructive product market competition and impatient finance on nonfinancial corporations in the neoliberal era. Review of Radical Political Economics, 35(3), 271-279.

Engelen, E. (2008). The case for financialization. Competition and Change, 12(2), 111-119.

Fernandez, R., \& Aalbers, M. B. (2016). Financialization and housing: Between globalization and varieties of capitalism. Competition and Change, 20(2), 71-88.

Fernandez, R., \& Aalbers, M. B. (2017). Housing and capital in the 21st century: Realigning housing studies and political economy. Housing, Theory and Society, 34(2), 151-158.

Fields, D., \& Uffer, S. (2016). The financialisation of rental housing: A comparative analysis of New York City and Berlin. Urban Studies, 53(7), 1486-1502.

Froud, J., Haslam, C., Johal, S., \& Williams, K. (2000). Shareholder value and financialization: Consultancy promises, management moves. Economy and Society, 29(1), 80-110.

Froud, J., Johal, S., Leaver, A., \& Williams, K. (2006). Financialization and strategy: Narrative and numbers. Routledge: London.

Gamble, A. (2014). Crisis without end? The unravelling of western prosperity. Palgrave Macmillan: Basingstoke.

Griffiths, M. (2011). We must fix it: Delivering reform of the building sector to meet the UK's housing and economic challenges. IPPR: London.

Gruis, V. (2008). Organisational archetypes for Dutch housing associations. Environment and Planning C, 26(6), 1077-1092.

HM Government (2015). £100 million boost for small housebuilders. Retrieved 10 August 2017 from https://www.gov.uk/government/news/100-million-boost-for-small-housebuilders.

Hodkinson, S. (2011). The private finance initiative in English council housing regeneration: A privatisation too far? Housing Studies, 26(6), 911-932.

Home Builders Federation. (2014). The barker review ten years on. London: Home Builders Federation.

Hulse, K., Reynolds, M., \& Martin, C. (2019). The Everyman Archetype: Discursive reframing of private landlords in the financialization of rental housing. Housing Studies. https://doi.org/10.1080/02673 037.2019.1644297.

Immergluck, D. (2010). The local wreckage of global capital: The subprime crisis, federal policy and high-foreclosure neighborhoods in the US. International Journal of Urban and Regional Research, 35(1), 130-146.

Jacobs, K., \& Manzi, T. (2019). Conceptualising of financialisation': Governance, organisational behaviour and social interaction in UK housing. International Journal of Housing Policy. https://doi. org/10.1080/19491247.2018.1540737.

Janoschka, M., Alexandri, G., Ramos, H. O., \& Vives-Miro, S. (2019). Tracing the socio-spatial logics of transnational landlords' real estate investment: Blackstone in Madrid. European Urban and Regional Studies. https://doi.org/10.1177/0969776418822061.

Jeanjean, T., \& Stolowy, H. (2008). Do accounting standards matter? An exploratory analysis of earnings management before and after IFRS adoption. Journal of Accounting and Public Policy, 27(6), 480-494.

Kay, J. (2015). Other people's money: Masters of the universe or servants of the people? Profile: London.

Langley, P. (2008). Sub-prime mortgage lending: A cultural economy. Economy and Society, 37(4), 469-494.

Lazonick, W. (2014). Profits without Prosperity. Harvard Business Review. Retrieved 13 October 2018 from https://hbr.org/2014/09/profits-without-prosperity.

Lazonick, W., \& O’Sullivan, M. (2000). Maximising shareholder value: A new ideology for corporate governance. Economy \& Society, 29(1), 13-35.

Lee, R., Clark, G., Pollard, J., \& Leyshon, A. (2009). The remit of financial geography before and after the crisis. Journal of Economic Geography, 9(5), 723-47.

Lyons, M. (2014). The Lyons Review: Mobilising across the nation to build the homes our children need. Retrieved 5 August 2018 from http://www.yourbritain.org.uk/uploads/editor/files/The_Lyons _Housing_Review_2.pdf.

Manzi, T., \& Morrison, N. (2018). Risk, commercialism and social purpose: Repositioning the english housing association sector. Urban Studies, 55(9), 1924-1942.

Martin, R., \& Turner, D. (2000). Demutualization and the remapping of financial landscapes. The Transactions of the Institute of British Geographers, 25(2), 221-241. 
Mazzucato, M. (2018). The value of everything. Making and taking in the global economy. Allen Lane: UK.

McCarthy, \& Stone, (2015). Prospectus. Retrieved 24 October 2018 from https://www.mccarthyandston egroup.co.uk/ /media/Files/M/McCarthy-And-Stone/documents/reports-and-presentations/repor t-prospectus-6-nov.pdf.

MHCLG (2016). An introduction to the Home Building Fund. Retrieved 15 September 2018 from https ://www.gov.uk/government/publications/home-building-fund/an-introduction-to-the-home-build ing-fund.

MHCLG (2017). Fixing our broken housing market. Retrieved 15 November 2017 from https://www.gov. uk/government/publications/fixing-our-broken-housing-market.

Mullins, D., Milligan, V., \& Nieboer, N. (2017). State directed hybridity?-the relationship between nonprofit housing organizations and the state in three national contexts. Housing Studies, 3(4), 565-588.

National Audit Office (2019). Help to Buy: Equity Loan scheme - progress review. HC 2216. National Audit Office: London

Norges Bank Investment Management (2017) Holdings. Retrieved 15 August 2018 from https://www.nbim. no/en/the-fund/holdings/holdings-as-at-31.12.2017/.

Payne, S. (2015). Exploring the impact of the recession on British volume housebuilders: A behavioural analysis. Built Environment, 41(2), 271-288.

Payne, S. (2019). Advancing understandings of housing supply constraints: Housing market recovery and institutional transitions in British speculative housebuilding. Housing Studies. https://doi. org/10.1080/02673037.2019.1598549.

Piketty, T. (2014). Capital in the twenty-first century. Cambridge, MA: Harvard University Press.

Roberts, J., Sanderson, P., Barker, R., \& Hendry, J. (2006). In the mirror of the market: The disciplinary effects of company/fund manager meetings. Accounting, Organization and Society, 31(3), 277-294.

Robertson, M. (2017). The great British housing crisis. Capital and Class, 41(2), 195-215.

Romainville, A. (2017). The financialization of housing production in Brussels. International Journal of Urban and Regional Research, 41(4), 623-641.

Smyth, S., Cole, I., \& Fields, D. (2019). From gatekeepers to gateway constructors: Credit rating agencies and the financialisation of housing associations. Critical Perspectives On Accounting. https://doi. org/10.1016/j.cpa.2019.102093.

Taylor Wimpey (2011). Results for the year ended 31 December 2010. Retrieved 12 April 2014 from https:// www.taylorwimpey.co.uk/corporate/investor-relations/reporting-centre/2011.

The Financial Times (2017). Equities. Retrieved 4 September 2017 from https://markets.ft.com/data/equit ies.

The Independent (2018). Persimmon shareholders revolt over chief executive's 'grossly excessive' $£ 75 m$ bonus, 25 April 2018. Retrieved 26 April 2018 from https://www.independent.co.uk/news/business/ news/persimmon-bonus-jeff-fairburn-bonus-pay-shareholder-revolt-company-agm-2018-a8322431. html.

Van Loon, J., \& Aalbers, M. B. (2017). How Real Estate became 'Just Another Asset Class': The financialization of the investment strategies of dutch institutional investors. European Planning Studies, 25(2), 221-240.

van der Zwan, N. (2014). Making sense of financialisation. Socio-Economic Review, 12, 99-129.

Wainwright, T. (2009). Laying the foundations for a Crisis: Mapping the historico-geographical construction of residential mortgage backed securitization in the UK. International Journal of Urban and Regional Research, 33(2), 372-388.

Waldron, R. (2018). Capitalizing on the state: The political economy of real estate investment trusts and the 'Resolution' of the crisis. Geoforum, 90, 206-218.

Wellings, F. (2006). British housebuilders: History and analysis. Blackwell: Oxford.

Wijburg, G., Aalbers, M. B., \& Heeg, S. (2018). The financialization of rental housing 2.0: Releasing housing into the privatized mainstream of capital accumulation. Antipode, 50(4), 1098-1119.

Wissoker, P. (2016). Putting the supplier in housing supply: an overview of the growth and concentration of large housebuilders in the United States (1990-2007). Housing Policy Debate, 26(3), 536-562.

Publisher's Note Springer Nature remains neutral with regard to jurisdictional claims in published maps and institutional affiliations. 